Research Paper

\title{
The Effect of Water Extract of Brown Seaweed on the Characteristic of Jelly Candy as a Functional Food
}

\author{
Anni Faridah \\ Faculty of Tourism and Hospitality, Universitas Negeri Padang, Jl. Prof. Dr. Hamka, Padang, West Sumatera, \\ Indonesia.
}

\begin{abstract}
Brown seaweed known as one of the source of the hydrocolloid (alginate) that is useful as thickener in food processing. Moreover, it also contains many beneficial compounds such as sulphated polysaccharides, phlorotannins, peptides, natural pigments, polyphenols, vitaminswhich can be developed as antioxidant, anticervix-tumor, hepatoprotector, and anti-diabetes. The use of wild brown seaweed which obtained from the coast of Nirwana in West Sumatera as an additive ingredient for jelly candy as a functional food was studied. Water extract of brown seaweed was added with various concentrations as much as 5\%,10\%, and $15 \%$. Sensory analysis was conducted for evaluating the product acceptance. Total phenolic compounds, antioxidant activity, the content in carbohydrate, fat, protein, ash, moisture were measure for determined the quality of most acceptable jelly candy. The most acceptable jelly candy was the product with $15 \%$ addition of brown seaweed extract. The addition of brown seaweed extract improved the functionality of candy jelly that indicated by increasing of total phenolic compound, antioxidant activity, the content of carbohydrate, fat, protein and ash. The utilization of wild brown seaweed at the coast of Nirwana in West Sumatera is promising in developing of diversity functional food such as jelly candy and others product.
\end{abstract}

Key Words: Brown Seaweed Extract, Functional Food, Jelly Candies, Quality.

\section{INTRODUCTION}

Seaweeds can be classified into three broad groups based on pigmentation: brown, red and green. Botanists refer to these broad groups as Phaeophyceae, Rhodophyceae and Chlorophyceae, respectively. Seaweeds represent the most important non-animal source of sulphated polysaccharides, [1] phlorotannins, peptides, natural pigments, polyphenols, vitamins and primary compounds such as proteins, carbohydrates, fats and nucleic acids in varying proportions. ${ }^{[2]}$ In addition, there is also an incomparably rich amount of minerals and trace elements content in seaweed due to their ability in retaining inorganic marine substances attributed to the features of their cell surface polysaccharides where several of these essential minerals can be found at relatively higher levels than in terrestrial food sources. The presence of these compounds attributes to their nutritional value to have therapeutic properties for health and disease management, such as antioxidant, antitumor, anti-inflammatory, anti-obesity, neuroprotective that making them suitable for becoming a part of functional food ingredients. ${ }^{[3,4]}$ In addition their nutritional compounds, hydrocolloids are naturally present in their cell walls. Various red and brown seaweeds are used to produce three hydrocolloids: agar, alginate and carrageenan. ${ }^{[5-8]}$ A hydrocolloid is a non-crystalline substance with very large molecules and which dissolves in water to give a thickened (viscous) solution. Alginate, agar and carrageenan are watersoluble carbohydrates that are used to 
thicken (increase the viscosity of) aqueous solutions, to form gels (jellies) of varying degrees of firmness, to form water soluble films, and to stabilize some products, such as ice cream (they inhibit the formation of large ice crystals so that the ice cream can retain a smooth texture). Due to these beneficial characteristics, Seaweeds is promising to be developed to increase the diversity of functional products.

Distribution for seaweeds namely brown seaweed had been found in some places in West Sumatera, Indonesia. One of them is in Nirwana Beach at Padang City. The availability of brown seaweed in this region is abundance; however, their utilization is still limited till date. Therefore, in the view of functionality and rheological properties, the utility of brown seaweed was optimizing as an additive ingredient for jelly candy in this study. Brown seaweed is characterized by natural brown color that derived from fucoxhanthin and natural thickener namely alginate. ${ }^{[9-15]}$ Candy is one of favorite confectionery foods among people from a wide range of age. Jelly candy is characterized by a soft and chewy texture typically conferred by a gelatin or pectin-based gel. Stated that chewy jelly candies made with different gelling agents and sweeteners offer certain texture characteristics and eating properties. Therefore, the unique properties of gelling agent affected to the quality of the products. The properties of natural brown color and alginate that obtained from brown seaweed in addition of their many beneficial nutrients could enhance the quality of existed jelly candies. The aims of this study was to evaluate the influence of addition brown seed extract on the consumer acceptances and its quality in order to get primary data for the development of functional foods based on the application of unutilized brown seaweed in West Sumatera.

\section{MATERIALS AND METHODS Materials.}

Brown seaweed was obtained from Nirwana beach coastal region, West
Sumatera, Indonesia. Other ingredients such as agar, sugar, egg, citric acid were purchased as commercial products from traditional market. The reagents for quality measurement were use as analytical grade from various suppliers.

\section{Preparation of brown seaweed water extract.}

Brown seaweed were collected by hand, washed with deionized water and dried by sun rise. Then they were blended and put in light protected glass bottles and kept in the refrigerator. Water-soluble extracts were prepared as described by Lemhadri et al. (2007), with some modifications. Twenty five grams of dried brown seaweed were homogenized with 375 $\mathrm{mL}$ of distilled water in a boiled chamber and boiled at $100{ }^{\circ} \mathrm{C}$ for $20 \mathrm{~min}$. The extracts were then filtered and evaporated by rotary evaporator until volume of extract was about $50 \mathrm{~mL}$. The obtained water extract used immediately for making the product.

\section{Making of Jelly Candy.}

Recipes for making jelly candy were adapted from traditional recipe as shown in Table 1. The experimental jelly candy was manufactured by adding $0,5,10$, and $15 \%$ of brown seaweed water extract. The addition of brown seaweed water extract was substitute the water part for each formula. Each treatment was repeated 3 times.

\section{Jelly Candy Sensory Evaluation.}

The samples were homogenously sliced and each assessor was provided with filtered water and asked to cleanse their palate between tasting. Sensory evaluation was conducted with 30 untrained assessors, between 18-25 years of age. Panelists indicated their sensory evaluation by anchored with $0=$ none, $1=$ dislike, $2=$ dislike moderately, $3=$ like moderately and $4=$ like. The sensory attributes were divided into four groups corresponding to shape, 
brownies, brown seaweed flavor and springiness.

\section{Chemical compounds analysis.}

In order to characterize the best product based on sensory evaluation, chemical analyses such as the content in carbohydrate, fat, protein, ash, moisture were done according to Association of Official Analytical Chemists procedures. The total phenol content (TPC) was determined according to the Folin-Ciocalteu method. The anti-oxidant activity was determined according to DPPH (2,2Diphrnyl-2-picrylhydrazyl) radicalscavenging activity method.

\section{Statistical analysis.}

All data were analyzed with one-way ANOVA to determine the differences among treatments. If differences were found, then further analysis was performed with Duncan's multiple range test.

\section{RESULTS AND DISCUSSION Sensory attributes.}

The result graph of sensory attributes showed that the different levels of brown seaweed were generally accepted (Fig.1). The addition of the water soluble extracts of brown seaweed seemed to affect products characteristics. The presence fucoxanthin and alginate in brown seaweed were affected to the characteristic of treated jelly candies. Significant differences were found between control and the other trials for jelly candies. The mean scores increased with increase in the extracts of brown seaweed concentrations in color, flavor and springiness attributes tested. As expected, the $15 \%$ extracts of brown seaweed was significantly different among trial samples. It was thought that the addition of brown seaweed resulting the strong color, flavor and springiness scores. The expectation in increment of brown color and springiness was becoming the key value of the use brown seaweed in product development of jelly candy. Moreover, the addition of the water soluble extracts of brown seaweed seemed not to affect product shape and taste uniformity (Table 2). Due to overall acceptability of jelly candy that was markedly for of $15 \%$ brown seaweed, it indicated that the presence of brown seaweed in products could enhance the consumer impression of jelly candy.

\section{Chemical composition of the most acceptable jelly candy.}

Table 3 indicates the chemicals composition of control and the most acceptable jelly candy by sensory evaluation with addition of $15 \%$ water extract of brown seaweed. The carbohydrate, lipid and moisture content of jelly candy were not significantly different to control. On the other hand, protein and ash content indicated significantly different result compare to control. The increasing of ash content which indicating the minerals and protein is an expected condition due to the characteristic of brown seaweed that contains high primary compounds and minerals. However, in the case of carbohydrate and lipid content, it seemed the addition of brown seaweed water extract was not affected to carbohydrate and lipid content in the product. It can be suggested that carbohydrate and lipid was not presence in brown seaweed water extract due to lack to of water solubility of each compound. Therefore, when extraction process, water as extraction solvent might be cannot withdraw the brown seaweed's contained carbohydrate and lipid as well. The absence of carbohydrate and lipid increment due to brown seaweed water extract addition, it could become an interesting since the product with low calorie and fat is also desired.

Since TPC and antioxidant activity are known as the basic indicator to recognize the beneficial influence of natural extract in many foodstuffs, next we also evaluated the TPC and antioxidant activity of control jelly candy and the most acceptable jelly candy. Figure 4 indicates the TPC and IC 50 of control and jelly 
Anni Faridah. The Effect of Water Extract of Brown Seaweed on the Characteristic of Jelly Candy as a Functional Food

candy with addition of $15 \%$ water extract of brown seaweed. The TPC of jelly candy was determined and calculated using gallic acid while the antioxidant activity was represent as IC50 values of jelly candy (IC50 value is the concentration of the sample required to inhibit $50 \%$ of radical). The TPC of acceptable jelly candy and control were 360 $\mathrm{mg} \mathrm{g}^{-1}$ and $301.5 \mathrm{mg} \mathrm{g}^{-1}$ of gallic acid in fresh weight sample (FW), respectively (Fig2). Meanwhile, the IC50 of acceptable jelly candy and control were $3.2 \mathrm{mg} \mathrm{L}^{-1}$ and $2.7 \mathrm{mg} \mathrm{L}^{-1}$, respectively (Fig2). Since the antioxidant activity is responsible to TPC, our result indicated a similar pattern of TPC and antioxidant activity of the jelly candy contain $15 \%$ water extract of brown seaweed compare to control.

Table 1. Formulation for Jelly Candies

\begin{tabular}{|c|c|c|c|c|}
\hline \multirow{3}{*}{ Ingredients } & \multicolumn{4}{|c|}{ Recipe } \\
\hline & \multicolumn{4}{|c|}{ Brown Seaweed Water Extract } \\
\hline & $0 \%$ & $5 \%$ & $10 \%$ & $15 \%$ \\
\hline \multicolumn{5}{|l|}{ Layer I } \\
\hline $\begin{array}{l}\text { brown seaweed water } \\
\text { extract }(\mathrm{mL})\end{array}$ & - & 50 & 100 & 150 \\
\hline Agar-agar (g) & 9 & 9 & 9 & 9 \\
\hline Nutrijell (g) & 30 & 30 & 30 & 30 \\
\hline Water $(\mathrm{mL})$ & 1000 & 950 & 900 & 850 \\
\hline Sugar $(g)$ & 500 & 500 & 500 & 500 \\
\hline Sodium benzoate $(\mathrm{g})$ & 0.25 & 0.25 & 0.25 & 0.25 \\
\hline Citric acid $(\mathrm{g})$ & 0.25 & 0.25 & 0.25 & 0.25 \\
\hline \multicolumn{5}{|l|}{ Layer II } \\
\hline Agar-agar (g) & 18 & 18 & 18 & 18 \\
\hline Nutrijell (g) & 15 & 15 & 15 & 15 \\
\hline Water $(\mathrm{mL})$ & 500 & 500 & 500 & 500 \\
\hline Sugar $(g)$ & 250 & 250 & 250 & 250 \\
\hline sodium benzoate $(\mathrm{g})$ & 0.25 & 0.25 & 0.25 & 0.25 \\
\hline Citric acid $(\mathrm{g})$ & 0.25 & 0.25 & 0.25 & 0.25 \\
\hline Salt (g) & 0.5 & 0.5 & 0.5 & 0.5 \\
\hline Eggwhite (g) & 60 & 60 & 60 & 60 \\
\hline
\end{tabular}

\section{Instructions}

\section{Layer I}

1. In a saucepan, mix the agar-agar, nutrijell, brown seaweed water extract, salt, sodium benzoate, citric acid with water. Stir in the sugar and bring to boil.

2. pour into a pan and then reduce the heat until warm

Layer II

1. In a saucepan, mix sugar, agar-agar, nutrijell, citric acid, sodium benzoate with water. Stir and bring to boil.

2. beat egg whites until stiff.
3. mixing no 2 to no 1 in the heat and then pour in to layer I

4. leave it overnight, cut and dry in two hour

5. coat the jelly with a thin layer of toss in sugar

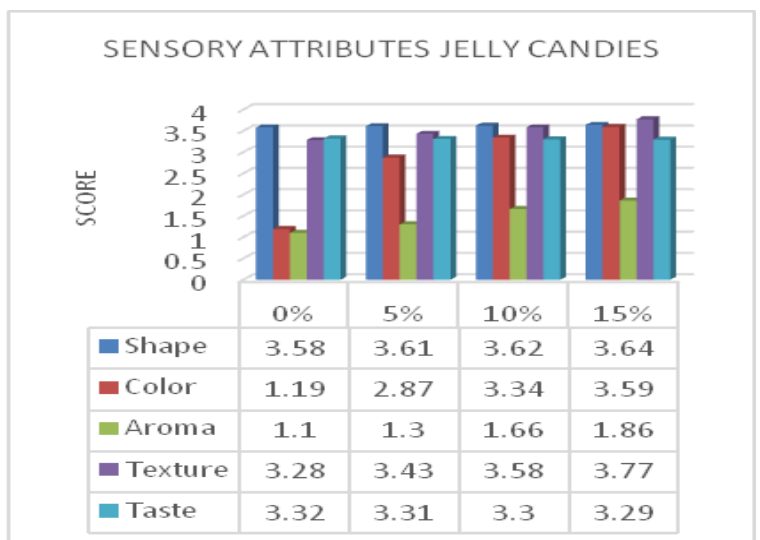

Fig 1. The Graph of Sensory Evaluation Result and Jelly Candies with Addition of Brown Seaweed Water Extract

Table 2. Ducan Test Result
\begin{tabular}{|l|l|l|l|l|}
\hline & $0 \%$ & $5 \%$ & $10 \%$ & $15 \%$ \\
\hline Shape & $3.58 \mathrm{a}$ & $3.61 \mathrm{a}$ & $3.62 \mathrm{a}$ & $3.64 \mathrm{a}$ \\
\hline Color & $1.19 \mathrm{a}$ & $2.87 \mathrm{~b}$ & $3.34 \mathrm{c}$ & $3.59 \mathrm{~d}$ \\
\hline Aroma & $1.1 \mathrm{a}$ & $1.3 \mathrm{~b}$ & $1.66 \mathrm{c}$ & $1.86 \mathrm{~d}$ \\
\hline Texture & $3.28 \mathrm{a}$ & $3.43 \mathrm{~b}$ & $3.58 \mathrm{bc}$ & $3.77 \mathrm{c}$ \\
\hline Taste & $3.32 \mathrm{a}$ & $3.31 \mathrm{a}$ & $3.3 \mathrm{a}$ & $3.29 \mathrm{a}$ \\
\hline
\end{tabular}

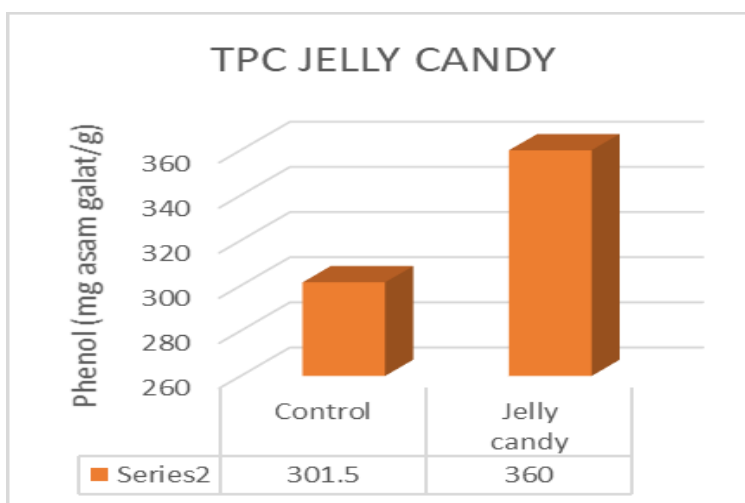

Fig 2. The graph of tpc results of control and mosts acceptable jelly candy by sensory evaluation.

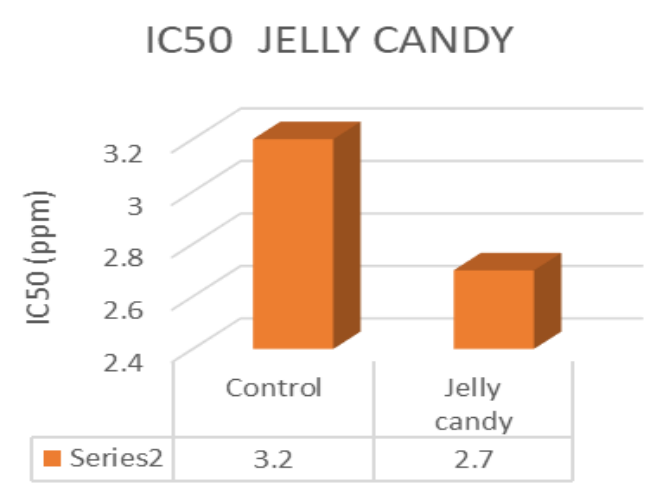

Fig 3. The graph of ic50 results of control and mosts acceptable jelly candy by sensory evaluation. 
Table 3. The Graph of Chemicals Composition Result of Control and Most Acceptable Jelly Candy by Sensory Evolution

\begin{tabular}{|l|l|l|}
\hline \multirow{2}{*}{ Content } & \multicolumn{2}{|l|}{ Value } \\
\cline { 2 - 3 } & Control & Experimen \\
\hline Carbohydrate & 80 & 77.044 \\
\hline Protein & 0.4978 & 1.499 \\
\hline Lipid & 0.376 & 0.4314 \\
\hline ash & 0.7073 & 1.6054 \\
\hline moisture & 18.5244 & 19.4202 \\
\hline
\end{tabular}

\section{CONCLUSIONS}

The use of wild brown seaweed as an additive ingredient of food such as jelly candy is promising to optimize the utilization of natural resources in the production of functional foods. Our results demonstrated that with appropriate levels of addition of brown seaweed could lead the change in color, flavor and springiness of jelly candies. Altogether, the $15 \%$ of the water extract brown seaweed addition showed the highest score of overall acceptability which also indicated higher nutritional values such as the content of protein, ash, TPC and antioxidant activity. Moreover, due to large variety of nutritional compound in brown seaweed that might be not extracted with well by water, therefore, the optimization of extraction efficiency of brown seaweed nutrient by several solvent should be considered further.

\section{REFERENCES}

1. De Souza MCR, Marques CT, Guerra Dore CM, Ferreira Da Silva FR, Oliveira Rocha HA, Leite EL. Antioxidant activities of sulfated polysaccharides from brown and red seaweeds. In: Journal of Applied Phycology. 2007.

2. Handayani T, Sutarno, Setyawan AD. Nutritional composition analysis of seaweed Sargassum crassifolium J. Agardh. Biofarmasi J Nat Prod Biochem. 2004;

3. Vinoth Kumar T, Lakshmanasenthil S, Geetharamani D, Marudhupandi T, Suja G, Suganya P. Fucoidan - A $\alpha$-d-glucosidase inhibitor from Sargassum wightii with relevance to type 2 diabetes mellitus therapy. Int $\mathrm{J}$ Biol Macromol. 2015;
4. Lee JB, Takeshita A, Hayashi K, Hayashi T. Structures and antiviral activities of polysaccharides from Sargassum trichophyllum. Carbohydr Polym. 2011;

5. Bertagnolli C, Espindola APDM, Kleinübing SJ, Tasic L, Silva MGC Da. Sargassum filipendula alginate from Brazil: Seasonal influence and characteristics. Carbohydr Polym. 2014;

6. El Atouani S, Bentiss F, Reani A, Zrid R, Belattmania Z, Pereira L, et al. The invasive brown seaweed Sargassum muticum as new resource for alginate in Morocco: Spectroscopic and rheological characterization. Phycol Res. 2016;

7. Mazumder A, Holdt SL, De Francisci D, Alvarado-Morales M, Mishra HN, Angelidaki I. Extraction of alginate from Sargassum muticum: process optimization and study of its functional activities. J Appl Phycol. 2016;

8. Fawzy MA, Gomaa M, Hifney AF, AbdelGawad KM. Optimization of alginate alkaline extraction technology from Sargassum latifolium and its potential antioxidant and emulsifying properties. Carbohydr Polym. 2017;

9. Miyashita K. The carotenoid fucoxanthin from brown seaweed affects obesity. Lipid Technol. 2009;

10. Jaswir I, Noviendri D, Salleh HM, Miyashita K. Fucoxanthin extractions of brown seaweeds and analysis of their lipid fraction in methanol. Food Sci Technol Res. 2012;

11. Hii SL, Choong PY, Woo KK, Wong CL. Stability studies of fucoxanthin from Sargassum binderi. Aust J Basic Appl Sci. 2010;

12. Limantara L, Heriyanto. Optimasi Proses Ekstraksi Fukosantin Rumput Laut Coklat Padina australis Hauck Menggunakan Pelarut Organik Polar. Ilmu Kelaut - Indones J Mar Sci. 2012;

13. Zailanie K, Purnomo H. Fucoxanthin Content of Five Species Brown Seaweed from Talango District, Madura Island. J Agric Sci Technol. 2011;1103-1105.

14. Nurhanif AE, Zaelanie K, Kartikaningsih $H$. Stabilitas fukosantin dari rumput laut cokelat (Sargassum cristaefolium) dalam berbagai $\mathrm{pH}$. THPi STUDENT J. 2013;1(1):2013.

15. Susanto E, Fahmi AS, Abe M, Hosokawa M, Miyashita K. Lipids, Fatty Acids, and Fucoxanthin Content from Temperate and Tropical Brown Seaweeds. Aquat Procedia. 2016;

How to cite this article: Faridah A. The effect of water extract of brown seaweed on the characteristic of jelly candy as a functional food. International Journal of Research and Review. 2019; 6(11):148-152. 